\title{
EL «PRINCIPIO DE CAPACIDAD SALVÍFICA» EN LA TEOLOGÍA DE ADOLPHE GESCHÉ
}

Fecha de recepción: 23 de febrero de 2021

Fecha de aceptación: 17 de marzo de 2021

RESUMEN: Adolphe Gesché estableció el «principio de capacidad salvífica»—salutarité - como la tarea propia de la teología. Ésta debía ser capaz de proponer la inteligibilidad de los conceptos propios de la fe cristiana para redescubrir a Dios y la salvación que sólo él puede dar. El presente estudio expone dicho principio, su origen y significado, así como su desarrollo en la obra Dieu pour penser. Muestra sus posibilidades — contra los límites de la existencia-, su fundamentación —la filiación-, su propuesta — la divinización-y su actualización —la revelación-.

PALABRAS CLAVE: teología fundamental; Adolphe Gesché; principio de capacidad salvífica; salvación; filiación; divinización; revelación.

\section{The «Salvific Capacity Principle» in Adolphe Geschés Theology}

ABSTRACT: Adolphe Gesché established the «salvific capacity principle» —salutaritéas the proper task of Theology. Theology had to be able to propose the intelligibility of the Christian faith concepts in order to rediscover God and the salvation that only he can give. This study presents this principle, its origin and meaning, as well as its development in Dieu pour penser. It shows its possibilities —against the existence limits-, its foundation - filiation-, its proposal — divinisation - and its actualisation —revelation-.

KEY WORDS: Fundamental Theology; Adolphe Gesché; salvific capacity principle; salvation; filiation; divinization; revelation.

\footnotetext{
Universidad Pontificia Comillas: sgmourelo@comillas.edu;

ORCID: https://orcid.org/0000-0002-2728-8556
} 
Con el presente estudio concluimos nuestra investigación sobre el carácter teológico-fundamental de la obra del teólogo Adolphe Gesché, Dieu pour penser ${ }^{1}$. Por ello, se sitúa en continuidad con los artículos previamente publicados sobre esta cuestión en Estudios Eclesiásticos ${ }^{2}$. Si en el precedente desentrañábamos el llamado "principio de responsabilidad» - en su aplicación a Dios y al ser humano, a la razón y a la fe, como principio metodológico-, en las líneas que siguen pretendemos focalizar nuestra atención y análisis en la tarea o la misión que el teólogo de Lovaina propuso a la teología. Esta debía regirse por el "principio de capacidad salvífica» —acuñado con el neologismo salutarité-.

En concreto, realizaremos una aproximación genética del concepto y de sus implicaciones formales, que nos pueden ayudar a definirlo. A partir de ello, iniciaremos una investigación diacrónica en Dieu pour penser, mostrando cómo es desarrollada esta capacidad salvífica en el mismo quehacer del teólogo belga, bajo el concepto de «salvación». Por estos motivos, las referencias utilizadas se circunscriben casi exclusivamente a su obra, exceptuando algunas sugeridas por el mismo autor u obligadas para su necesaria contextualización.

\section{EMERGENCIA Y DERIVACIONES DEL PRINCIPE DE SALUTARITÉ}

La digitalización del fichero personal de Adolphe Gesché, puesto a disposición para los investigadores por la Universidad Católica de Lovaina, es una referencia esencial para el estudio de cualquier tema abordado

1 A. Gesché. Le mal. Dieu pour penser I. Paris: Cerf, 1993; Id. L’homme. Dieu pour penser II. Paris: Cerf, 1993; Id. Dieu. Dieu pour penser III. Paris: Cerf, 1994; Id. Le Cosmos. Dieu pour penser IV. Paris: Cerf, 1994; Id. La Destinée. Dieu pour penser V. Paris: Cerf, 1995; Id. Le Christ. Dieu pour penser VI. Paris: Cerf, 2001; Id. Le Sens. Dieu pour penser VII. Paris: Cerf, 2003. Se citarán por el título abreviado en francés, seguido de las páginas en esa edición y, después, de la edición en castellano, cuyas referencias están en la bibliografía final (p. e. cf. infra nota 18). Ordinariamente, seguiremos la traducción de éstas últimas.

2 S. García Mourelo. "La monstratio theologica de Adolphe Gesché. Inspiración teológico-fundamental de su obra". Estudios Eclesiásticos 92 (2017): 3-32; Id. "El 'principio de responsabilidad' en la teología de Adolphe Gesché". Estudios Eclesiásti$\cos 96$ (2021): 87-131. 
por él ${ }^{3}$. En estas notas pueden descubrirse y rastrearse las matrices, el desarrollo y las derivaciones de sus ideas, a veces entresacadas de sus lecturas, de la participación en conferencias, de los cursos impartidos por él o de sus propias reflexiones.

Las referencias sobre el principe de salutarité las encontramos acotadas en la década de los ochenta. La primera noticia corresponde a una ficha datada a finales de noviembre de 1980, donde indica que esa idea surgió en uno de los cursos impartidos el año anterior: "Propuse, hace aproximadamente un año, en un curso, el principio de salutarité. Se trata de Dios. El concepto opuesto sería el del principio Adversarité y concierne al demonio ${ }^{4}$. La referencia sitúa el origen del concepto en el curso 1979-1980, donde impartió unas lecciones de cristología — propuesta de una teología de la confesión «Jesús, hijo de Dios» e interpretación cristiana del Crucificado-, y un Seminario de Dogmática Especial sobre la Creación ${ }^{5}$. Pese a que ambas cuestiones remiten al concepto de salvación, la inmediata reflexión posterior —en el primer lustro de los 80-, indica que la primera implicación del principe de salutarité se circunscribe en el ámbito de la epistemología. En concreto, al modo de elaborar la reflexión teológica y a su contribución específica. Tras un congreso, en diciembre de 1981, Gesché escribía:

«Salutarité. Qué triste ver este congreso sobre Dios, etc., al ver que allí la gente se volvió hacia sí mismos, hablando de la fe y de Dios por la fe, la religión, etc., pero no para otros, como salvación. La teología sólo tiene sentido si no es preservación de sí misma, sino que se orienta hacia una contribución (que no quiere decir que no deba profundizar, pero para aportar algo). Sin el principio de salutarité, la teología de la fe y la religión giran sobre sí mismas, incluso de forma apropiada para los intereses institucionales o ideológicos (teológicos), como si pudiera ser un objeto para sí misma: religión para uso interno que (también) trata para sí misma y por sí misma. Estos no son creyentes que hablan,

\footnotetext{
3 A. Gesché. Fichier numérisé d'Adolphe Gesché. Disponible bajo acreditación en: https://bib.uclouvain.be/gesche/fr

${ }^{4}$ NP. XVI, 13 (29-11.80). be.uclouvain.fichiergesche.demon_14. Las siglas NP hacen referencia al título que él mismo dio a sus cuadernos: «Ne pereant», evocando la traducción Vulgata de Jn 6,12: «ut autem impleti sunt dixit discipulis suis colligite quae superaverunt fragmenta ne pereant».

5 Cf. J.-F. Gosselin y P. Rodrigues. "Bibliographie”. En La margelle du puits. Adolphe Gesché, une introduction, dirigido por B. Bourgine, P. Rodrigues y P. Scolas, 475. Paris: Cerf, 2013.
} 
sino científicos que (también) tratan de esas cuestiones. No viven de ellas, más que en el sentido profesional del término» ${ }^{6}$.

Según su propio testimonio, Gesché reclama una teología en salida, como estamos acostumbrados a escuchar en el actual pontificado, que no se mire así misma si no es para ofrecer la Buena Noticia que ella porta. Más que erudición, la teología debe ser propuesta de salvación. El Dios de la fe cristiana es Dios-para-todos, en especial para quienes no lo conocen, no Dios-para-algunos. Por eso, la teología, como discurso sobre Dios, ha de establecer un diálogo más allá de su propio ámbito, donde se encuentra segura pero aislada, y los teólogos han de vivir su labor como una diakonía intelectual en favor de los otros — los que están al margen de la fe-, so pena de convertirse en meros profesionales de una materia alejada de su propia vida.

Estas primeras reflexiones, sobre el principio de capacidad salvífica, verán la luz al año siguiente - 1982 - en su colaboración al primer volumen de B. Lauret y F. Refoulé, sobre la Iniciación a la práctica de la teología. En ella subraya que la teología «debe tener el carácter de una invitación a la salvación» ${ }^{7}$. Sabedor de que la salvación sólo proviene de Dios, el discurso teológico debe «ser capaz de dar, en cuanto pensamiento y palabra, todas sus posibilidades de salvación, mediante unos conceptos realmente operativos y unos enunciados que expresen el dinamismo de la fe». Es más, se pregunta si, en un contexto donde se cuestiona el carácter científico de toda ciencia, "¿no consistirá el de la teología dogmática en lo que yo llamaría "el principio de capacidad salvífica”? [...] el carácter "científico” de esta ciencia sería su capacidad salvífica, su capacidad para invitar a la salvación».

En esta línea, las anotaciones de los dos años posteriores profundizan en este estatuto propio de la teología. Si su objeto propio es Dios, la salvación que éste propone al ser humano, su cientificidad, ha de ser la salutarité. A diferencia de la filosofía, que se relaciona con el sentido, y de la ciencia, que lo hace con la explicación, la teología está vinculada íntimamente con la salvación, porque «la felicidad, la plenitud es algo que se juega ante Dios y solo ante Dios, y lo único que puede realizarse

${ }^{6}$ NP. XVII, 107 (27.12.81). be.uclouvain.fichiergesche.theologie_305.

7 A. Gesché. "Teología dogmática". En Iniciación a la práctica de la teología, I. Introducción, editado por B. Lauret y F. Refoulé, 288-289. Madrid: Cristiandad, 1984 (1982). Las citas de este párrafo son de esta referencia. 
ante Dios» ${ }^{8}$. Ahí, en Dios, es donde se encuentra la regla de verificación de su propio discurso. Sería un error pensar que la demostración de su validez fuese de carácter positivo — positivismo bíblico o magisterial—, pues caería en una autorregulación tautológica9 . Por eso, el principio de verificación de la teología no es algo que pueda ser controlado por ella, por el sencillo motivo de que aquello de lo que habla o, mejor, de Quién habla, escapa a esa pretensión ${ }^{10}$. No puede ni debe pretender manejarlo, puesto que ni Dios ni su salvación pueden ser apresados en un discurso, so pena de caer en la idolatría, el voluntarismo o la gnosis ${ }^{11}$.

Las fiches del segundo lustro de los 80 sobre esta cuestión, desarrollan el principe de salutarité como un vínculo entre la vocación del sacerdote y las consecuencias pastorales del quehacer teológico ${ }^{12}$. Gesché entendía que, en su única vocación como sacerdote y teólogo, tenía la misión de compartir la palabra y el pan, pero si la teología tenía el deseo de invitar a la salvación, entonces la palabra que él debía compartir debía ser una palabra de salutarité ${ }^{13}$. El sacerdote era para él un «ministro del Libertador (quasi una definición de Dios) [...]. Un inmenso ministerio de amor que libera al hombre ${ }^{14}$ de todos los miedos, servidumbres y falsas culpabilidades. Un servicio en el que la teología, bajo el principe de salutarité, podía y debía ayudar, porque los miedos conducen al integrismo y al fundamentalismo, a la estupidez fría y agazapada. Esta manera de entender el quehacer teológico lo convierte en «una pastoral de la inteligencia» ${ }^{15}$, en un servicio inexcusable que evita su repliegue en la erudición, porque la finalidad de toda erudición, en el ámbito de la teología, no es otra que volver a proponer, como si se tratara de un segundo nacimiento, una hermenéutica de la fe válida para el hombre de hoy ${ }^{16}$.

${ }^{8}$ NP. XX, $55-56$ (11.4.83). be.uclouvain.fichiergesche.theologie_sciences_18. Sobre la distinción entre la Filosofía, la Ciencia y la Teología, también de esa época, cf. NP. XXVII, 59 (28.10.84). be.uclouvain.fichiergesche.creation_372.

9 Cf. NP. XX, 107-108 (25.5.83).be.uclouvain.fichiergesche.epistemologie_4.

${ }^{10}$ Cf. NP. Ibid. be.uclouvain.fichiergesche.epistemologie_5.

11 Cf. NP. XXVI, 97 (12.9.84). be.uclouvain.fichiergesche.fauxdieux_1.

12 Cf. NP. XLVII, 66-67 (23.6.88). be.uclouvain.fichiergesche.hermeneutique_55.

13 Cf. NP. XXXVII, 34 (30.8.86). be.uclouvain.fichiergesche.pretre_129.

14 NP. LIX, 74 (24.8.90) be.uclouvain.fichiergesche.pretre_211.

15 NP. LIX, 75 (25.8.90). be.uclouvain.fichiergesche.theologie_754.

16 NP. XXVI, 97 (12.9.84). o. c. 
Desde este acercamiento, el principio de capacidad salvífica puede definirse como el principio epistemológico y metodológico de la teología; regula su carácter científico y orienta el camino hacia su meta. La teología, como logos sobre Dios, no puede tener otra finalidad que profundizar en su Misterio siempre en relación con el enigma del ser humano. Un Misterio que propone comprensión, sentido y, ante todo, destino a la existencia humana. Una teología que no sea significativa para el hombre, en esta dirección, sería una falsificación; traicionaría su propia vocación, que es comunicar a Dios y su salvación. Como escribió en su última lección: «El deber secular de la teología, su deber antropológico, es traer a Dios al hombre y, así, proporcionarle o proponerles algo propio» ${ }^{17}$.

Este origen y destino del quehacer teológico, concentrado y decidido en Dios, es el que regula su carácter científico, su propia normatividad, distinguiéndose de otros saberes e invitando a confrontarse con el origen y meta de su andadura: con Dios. Lejos de ser poseído, con él y en él debe ser confirmado su discurso. Éste, lejos de ser una ilusión, se muestra como una alusión; como el eco de la palabra proferida en la eternidad que remite y conduce a ella, porque, aunque le pertenezca, no la posee.

Con estas matrices especulativas, centradas en una década, pero omnipresentes en toda su obra, no es de extrañar que Gesché dedicase un volumen específico de Dieu pour penser a la cuestión de la salvación, bajo el título de La Destinée. En él, a diferencia de los otros que completan la colección, la mayoría de los capítulos no son recopilaciones o reelaboraciones de artículos previos, sino que fueron redactados ex profeso para este tema central en su vocación como sacerdote-teólogo. Creemos que el primer capítulo de esta obra representa, in actu, el principio de capacidad salvífica del discurso teológico ${ }^{18}$. A partir de él, veremos cómo se conectan la mayoría de los temas de su obra, resultando una propuesta válida y sugerente, tanto para la teología como para quien se acerque a ella.

\subsection{La SALVACIÓN, EPICENTRO DEL PRINCIPIO}

Ante la idea de salvación se ciernen las sombras de la sospecha y el temor. Por eso Gesché comenzará por restituir este concepto acudiendo

17 A. Gesché. La Teología. Salamanca: Sígueme, 2017, 25.

18 Cf. La Destinée, 27-69/29-72. 
a su etimología. Sería una paradoja querer mostrar con conceptos operativos el mensaje de la fe para transmitir su capacidad salvífica y que la semántica de este mismo principio supusiese la primera piedra de tropiezo.

Si bien la idea de salvación se asocia inicialmente a aquello de lo que se necesita ser salvado — el mal, el pecado, etc.—, su etimología remite a una idea positiva y no a la negatividad que soluciona. "Salvar» tiene que ver con "salud", con un estado de bienestar integral, de solidez y fortaleza. La semántica evoca el hecho de estar completo y haber, por ello, llegado a cumplimiento. ¿Quién no desea gozar de semejante estado vital aun estando aparentemente ausente de limitaciones y constricciones? Así, con la idea de salvación se pone al descubierto el más profundo deseo del hombre, sea creyente o no: tener conciencia de que ha llegado, desde el fondo de sí mismo, "a alcanzar esa profunda satisfacción y esa dicha de haber vivido una vida con sentido, de no haber pasado al lado de nuestra vida y de nuestro ser, de haber conseguido esa profunda dicha de una vida lograda y cumplida» ${ }^{19}$.

Con todo, en este deseo de realización plena, que lleva al ser humano a tomar decisiones y opciones, a proyectar su futuro de la manera más satisfactoria posible, no hay ausencia de impedimentos. Gesché es bien consciente de ello. Creemos que se sitúa lejos de un optimismo fácil e inocente, de apartar la mirada ante las situaciones dolientes y ante las fuerzas que coartan su cumplimiento. No por casualidad señala tres grandes obstáculos que parecen oponerse a ella: la muerte, el mal y la fatalidad, dedicando al segundo de ellos el primer volumen de Dieu pour penser. Tales asechanzas no tienen por qué tener una vinculación directa con la idea de pecado, como en ocasiones se pretende inculpar a quienes anuncian la salvación. En efecto, no se hace necesario un presupuesto moral que requiera la salvación, ni una dominación y oscurecimiento de las conciencias que reclamen la luz y la liberación de la condenación y la culpa. La idea de salvación se impone por la misma naturaleza del hombre, lo que no excluye que en su existencia se tope con impedimentos y dificultades, en ocasiones, provocadas por un fallido ejercicio de la libertad humana. En ellas nos detenemos.

19 La Destinée, 31/32-33. 


\section{EL LUGAR DE LA SALVACIÓN: LA ENCRUCIJADA DE LA EXIS- TENCIA}

En su existencia el hombre se encuentra, sin pretenderlo, con los tres obstáculos señalados. Forman parte de la vida, aunque la vida no se reduzca a ellos. Son ineludibles e infranqueables. Tarde o temprano todo ser humano se encuentra con ellos en su propia experiencia, o es testigo de las dificultades que provocan en quienes lo acompañan. Podemos decir que son inmanentes a la propia vida porque pertenecen a ella, pretendiendo, en ocasiones, apoderársela y reducirla. Por este motivo, que se impone por sí mismo, Gesché tratará de ir más allá de dichos límites, trascendiéndolos — por lo menos conceptualmente-, desde y hacia la palabra que el logos de la fe tiene sobre ellos. Ante la imposición de las restricciones de la inmanencia, la teología deberá proponer la trascendencia desde sus propias categorías, mostrando su capacidad de transmitir la salvación que la ha provocado.

\subsection{LA INMANENCIA DEL LÍMITE EXISTENCIAL}

\subsubsection{La muerte}

El hombre es un ser limitado, contingente y la muerte es la representación más clara y dramática de su finitud. Llamada «el último enemigo» por Pablo (1Cor 15,26), la muerte acecha con su mortal aguijón (cf. 1Cor 15,55) detrás de cada acontecimiento de la vida. Ante ella el miedo y el temor se imponen. Por mucho que la ciencia, la filosofía, la sociología o el marketing hayan querido hacerla comprensible o tratado de suavizarla o, incluso, de maquillar sus efectos en quienes se introducen en ella y en quienes sufren la pérdida de un ser querido, la muerte nos asusta ${ }^{20}$. Por definición, es el término de la vida. Un fin que es sinónimo de tristeza, de desdicha, de mal, pues corresponde, en definitiva, a una falta de ser y de libertad; rasgos característicos del ser humano que son el fundamento de todo lo que le hace experimentar su propia conciencia. La muerte corta toda relación intramundana, nos encierra y nos anula. Es ausencia de comunicación, pues aparentemente dejamos de

20 Ibid., 35/37. 
poder expresar lo que somos y de percibir lo que otros nos comunican. No en vano, la tradición veterotestamentaria, aún presente en algunas problemáticas del Nuevo Testamento - las creencias de los saduceos, la polémica de Pablo en 1Cor-, consideraba que, después de la muerte, a los hombres les esperaba el sheol, el reino de los muertos, donde el ser humano sobrevivía miserablemente alejado de los vivientes y de $\operatorname{Dios}^{21}$.

Aun con estas características, la muerte, en la reflexión ordinaria, ha facilitado el encuadramiento histórico del hombre. Le hace caer en la cuenta de que sus días tienen un comienzo y un fin, lo que reviste un aspecto positivo. Gracias a la muerte, el ser humano es consciente de que no todo está al alcance de su mano, de que un día dejará de tener como posibilidad lo que se proponga, de que habrá terminado su existencia sin haber logrado, quizá, todos sus deseos ${ }^{22}$. La conciencia de su temporalidad puede empujar al hombre a no desaprovechar cada momento de la existencia para realizar su proyecto. Saber que todo se puede acabar puede llevar al hombre, en el mejor de los casos, a no malgastar su vida y a gastarla de la mejor manera posible. Puede suscitar la pregunta por el sentido de la vida, por el significado de la historia y, en definitiva, por su propia identidad.

Con todo, siendo ésta la máxima positividad dentro de la mayor negatividad, en el fondo de ella late la resignación de quien se sabe perdedor apenas iniciada la partida, de quien ha claudicado ante la mayor dificultad, de quien no ha visto la totalidad de posibilidades que le brinda la realidad y que pueden dar solución —-salvación—a semejante problema. "¿Qué hombre podrá vivir sin ver la muerte? ¿Quién escapará a las garras del sheol?»(Sal 89,49).

\subsubsection{El mal}

«El mal es lo más terrible que hay en el mundo ${ }^{23}$. Incluso una posible reflexión sobre él podría caer en la perversión de dar razón —logos-, a lo que nuestro autor califica como lo irracional por excelencia, pues carece de logos fundador que lo motive e inaugure ${ }^{24}$. Gesché, desde la perspectiva

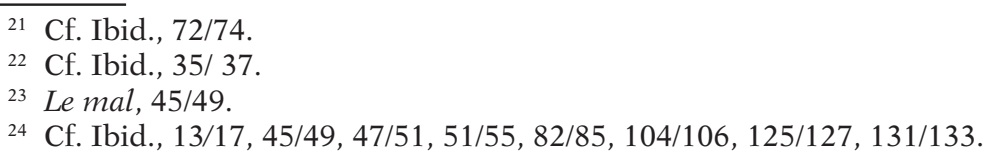


de la teología narrativa, muestra que el mal es algo como imprevisto para Dios en su propia creación. No pertenece a su plan ni tiene su origen en el hombre, aunque éste, llegado el momento, lo consienta ${ }^{25}$.

El mal se presenta como una negación incomprensible, sufrida, contemplada, tolerada o infringida. Así, desde la perspectiva clásica (san Agustín) se ha clasificado el mal como malum culpae, el mal activo - quien lo comete-y el malum poenae, el mal pasivo — quien lo padece como pena o castigo-. Esta clasificación adolece de la búsqueda inquietante de un culpable que lo origine y, como señala Gesché, conviene aportar alguna matización. No sea que preocupados en buscar al culpable, olvidemos la respuesta que debemos dar y nuestra atención a la víctima ${ }^{26}$. Esta tendencia del ser humano por comprender, analizar, buscar los orígenes de las cosas, ha llevado a acentuar la culpabilidad, bien asumiéndola personalmente o haciendo cargar a otros con este peso.

En este camino de dilucidación se constata la dificultad de conocer el origen del mal. Las diversas teodiceas terminan por situarlo en el hombre o en un principio de carácter gnóstico o maniqueo, o por conceptualizarlo como mysterium iniquitatis. Desde nuestro logos, las imágenes bíblicas del demonio, el diablo o su concreción en la serpiente nos ayudan a excluir su proveniencia de Dios o del ser humano. Por eso resulta pertinente añadir el malum calamitatis, el mal de desgracia; un mal que es inmerecido, inmotivado y que, sin embargo, se sufre ${ }^{27}$. Por estas razones, junto a la teodicea clásica, quizá sea necesario añadir, como matriz especulativa, dos conceptos que aporten la luz que en ocasiones se puede necesitar.

En primer lugar, una «antropodicea $»^{28}$, una defensa del hombre culpado por la fácil y rápida absolución de Dios en el problema del mal, haciendo recaer el origen de éste en el ejercicio fallido de la libertad. Por lo demás, el mal no representa un atentado contra Dios, sino contra su voluntad sobre nosotros. No es a Dios a quien hay que liberar de los efectos del mal, sino al hombre que los sufre o los consiente. De aquí nace el segundo concepto: una «teodicea negativa ${ }^{29}$. Con ella se quiere

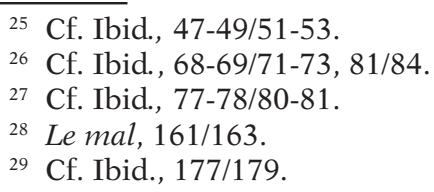


expresar cómo, desde la fe, se descubre que la identidad del Dios cristiano se muestra como combatiente contra el mal. No es el mal el que niega la posibilidad o las capacidades de Dios, sino Dios el que hace una objeción contra el mal. «La razón no puede nada contra el mal $»^{30}$ y nuestras propias fuerzas tampoco. Lo expresó de forma clarividente Pablo en la Carta a los Romanos: «querer el bien lo tengo a mi alcance, más no el realizarlo, puesto que no hago el bien que quiero, sino que obro el mal que no quiero» (Rom 7,18b-19). Por eso quizá no sea una locura acudir a un Tercero Trascendente que se muestre extraño - en el mejor sentido de la palabra- y contrario al mal y que, por su propia naturaleza trascendente, pueda arrancarnos desde lo alto de su dominio. "Menguados estaban y abatidos, presa del mal y la aflicción» (Sal 107,39) ¿Quién se acordará de ti, hombre, para absolverte de tal pesada carga?

\subsubsection{La fatalidad}

Es la ausencia frecuente y clamorosa de libertad. En ocasiones se muestra en toda su crudeza y en otras de una manera serena y resignada: la herencia, los condicionamientos culturales y biológicos, las enfermedades endémicas, los devenires de la naturaleza, etc. En definitiva, los imprevistos que nos hacen caer en la cuenta de que estamos bajo las condiciones de la existencia. Ante tales situaciones se multiplican los recursos a expresiones como "estaba escrito», "tenía que pasar»o incluso, «Dios lo ha querido así»» ${ }^{31}$. En ellas parece que se está justificando la fatalidad, como si de alguna extraña manera estuviésemos «marcados para la desdicha» ${ }^{32}$ y solamente tuviéramos un destino trágico anticipado en el eterno retorno de la desgracia. La hipótesis de Gesché es que, en el fondo, nos subyuga la concepción griega del tiempo. El dios Chronos, que controlaba en la distancia las edades y los tiempos haciendo girar la rueda del zodiaco y devorando a sus hijos, resurge en este neofatalismo que invade nuestro pensamiento. En esta situación, pocas visiones del tiempo y de la historia han sabido dar una respuesta a este callejón sin salida y sin posibilidad de retroceso. Los griegos fueron capaces de imaginar, junto al chronos —el tiempo marcado por

\footnotetext{
30 Le mal, 177/179.

31 La Destinée, $36 / 38$.

32 Le Sens, 89/102.
} 
la caducidad, el tiempo de nuestra vida biológica-, otra temporalidad, la realmente verdadera, el aiôn o aeveus —el «tiempo» de la eternidad, el tiempo de los dioses-, totalmente alejado e inaccesible al ser humano que sólo se podía mover en la imitación móvil del chronos (Platón). Con esta tajante división: tiempo-eternidad, movilidad-inmovilidad, es fácil imaginar cuál de ellas era objeto de anhelo para los griegos - y de anhelo frustrado, pues carecían del nexo capaz de articular ambas categorías-y cuál de desprecio y de huida ${ }^{33}$.

De alguna manera esto es lo que hoy en día sucede, aunque le demos otros nombres: nihilismo, escepticismo radical, realismo materialista, etc. Consciente del drama en que vive, parece que el ser humano ha mermado su capacidad de imaginar unos cielos nuevos y una tierra nueva (cf. Ap 21,1) y se conforma con soñar de manera limitada - itremenda paradoja! - , pues en su interior se levanta el muro infranqueable del fatum, impidiendo trascender el límite que es una parte de su existencia. En el futuro nada nos aguarda, ni identidad, ni destino, ni esperanza. "El hombre es semejante a un soplo, sus días, como una sombra que pasa» (Sal 144,4) ¿Quién se acordará de ti para absolverte de tal condenación?

\subsection{LA TRANSCENDENCIA DEL LÍMITE CONCEPTUAL}

Ante estos tres límites expuestos ¿qué dirá el logos de la fe? Legitimado como potencia gnoseológica, acreditado por padecer en sí mismo dichos avatares, ¿cómo los sorteará? ¿Cómo se liberará de ellos para mostrar su capacidad salvífica? Lo hará desde dentro de ellos mismos. No los esquivará, ni los pondrá entre paréntesis. Obviarlos o dar una respuesta desde la distancia, no sería más que falsificarse a sí mismo como logos y a su propuesta. Ante la muerte, el mal y la fatalidad, como conceptos y, sobre todo, como hechos concretos de la experiencia, la fe cristiana propone, como contenidos de sí misma, tres conceptos verificables desde la experiencia del creyente: la resurrección, el pecado original y la eternidad.

33 Cf. La Destinée, 108/110; Le Cosmos, 187-188/307. 


\subsubsection{La resurrección}

La fe cristiana proclama la resurrección como el acontecimiento que rompe y transciende el momento final de la vida del ser humano, desde su propio interior ${ }^{34}$. Toma este concepto como perteneciente a su núcleo fundamental, como experiencia articulada en el dato de fe. Fundado en la resurrección de Jesús, tal acontecimiento se hace extensible a todo el género humano y lo rebasa hasta alcanzar a toda la creación. Esto es lo que confiesa nuestra fe, pero ¿qué significación alcanza dicho suceso, como contrapartida a la muerte, para el hombre y el creyente hodiernos? ¿Cuál es el nexo que nos permite hablar de una extensión de la resurrección de Jesús hacia todo lo creado, para mostrar como salvífica tal propuesta?

Para profundizar en la significación teológica de la muerte y resurrección de Jesús, Gesché acudirá a la tradición del descenso a los infiernos. Es significativo que, para dar cuenta de la resurrección, nuestro autor utilice esta lectura del acontecimiento salvífico, pudiendo resultar una de las más problemáticas actualmente para su comprensión. Este hecho es señal de su especial querencia hacia elaboraciones teológicas de la tradición caídas en desuso, poniendo al descubierto su potencialidad especulativa por la dimensión holística que pueden alcanzar. Si bien es cierto que esta tradición corre el riesgo de caer en un discurso mítico o gnóstico, no lo es menos que su comprensión posibilita la lectura cósmica de tal acontecimiento, atisbando, así, su anchura, su longitud, su altura y su profundidad (cf. Ef 3,18); como lo constataron los Padres griegos, que asumieron este riesgo para poner de manifiesto la importancia y la relevancia, tanto de la cuestión específica a tratar, como de las posibilidades que este tipo de racionalidad podría brindar al quehacer teológico ${ }^{35}$.

El fundamento bíblico de esta tradición se encuentra en el discurso de Pedro el día de Pentecostés (cf. Hch 2,22-24) — con grandes paralelismos al de Pablo en Hch 13,26-42-. En ambos, la importancia reside en la

\footnotetext{
34 No entramos aquí en las cuestiones de la retribución total y otras relacionadas con ella, que, por otra parte, no son objeto de estudio para nuestro autor. A. Gesché, por el carácter más «fundamental» que «dogmático» de su obra —si se nos permite esta división, quizá excesivamente tajante-, no suele detenerse tanto en el desarrollo dogmático de los núcleos fundamentales de la fe, cuanto en la significación —plausibilidad, credibilidad y relevancia- que éstos pueden alcanzar para el hombre contemporáneo.

35 Cf. Le Christ, 162-164/172-174.
} 
secuencia espacial de los lugares de la resurrección: tierra-infiernos-cielo, en divergencia con el esquema espontáneo que solemos tener de este acontecimiento: tierra-salida del sepulcro y vuelta a la tierra-acceso al cielo. El primer esquema de corte «mitológico» resulta, a juicio de nuestro autor, de mayor potencialidad teológica para «comprender el gesto salvífico de Cristo desde su muerte hasta su ascensión a la derecha del Padre» ${ }^{36}$. Es el que da cuenta con mayor hondura de la significación de la resurrección respecto de la muerte. La bajada de Jesús a los infernos hace emerger la relevancia de tal suceso en varias perspectivas - fundamentalmente cristológica, antropológica y soteriológica-, extrayendo dos consecuencias fundamentales.

En primer lugar, desvelando la identidad del Dios cristiano que no queda indiferente o ausente del mayor límite impuesto a la existencia, mostrado, así, su omnipotencia ${ }^{37}$. Dios, en su Hijo, conoce ese lugar. «Jesús ha conocido la muerte sin ser dispensado de ella; la ha vivido con todas sus angustias, que no se limitan a los dolores físicos de la

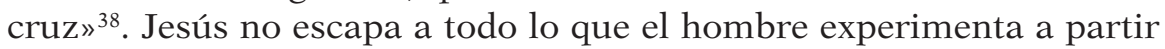
del pecado. Si bien, él no es presa del pecado, asume en sí mismo sus últimas consecuencias ${ }^{39}$. Así, con la bajada a los infiernos se representa el final del itinerario kenótico de la encarnación. En este recorrido los infiernos no son considerados como un lugar, sino como un estado:

\footnotetext{
${ }^{36}$ Le Christ, $167 / 178$.

37 Esta es la manera, según Gesché, de comprender mejor el tema de Cristo pantokrátor (cf. Le Christ, 172, note 1/183, nota 85).

${ }^{38}$ Le Christ, 169/180. Las cursivas son del autor. Él mismo precisa en nota el siguiente comentario: «Aun cuando, a diferencia de los demás, él sólo la ha conocido durante tres días, resulta sin embargo que eso es precisamente la resurrección. El hapax consiste en que un hombre, que estaba realmente muerto, pueda estar ya en el cielo (cosa que no ocurre ni con Lázaro ni con David)».

39 Las relaciones entre el pecado y la muerte, aunque no son directas, se establecen desde la tradición bíblica entendiendo la muerte como consecuencia del pecado (cf. Rom 5-6); la separación radical del ser humano (muerte) es vista como consecuencia de las sucesivas separaciones (pecado) originadas desde Adán, en el relato etiológico de la creación. Tal conexión fue retomada por san Agustín con una interpretación incorrecta de Rom 5,12-21 y posteriormente ratificada en el Concilio de Cartago (418) que asumirá la muerte como pena del pecado original, heredado de Adán (cf. DH 223). Nuestro autor no hace referencia a estos datos, aunque no obvia tal relación. Hace observaciones de cariz más fundamental, poniendo de manifiesto su conexión con la idea de límite y obstáculo para lograr el destino. Cf. La Destinée, 90-92/92-94.
} 
el de la muerte en cuanto vida-separada-de-Dios. Desde aquí podemos hablar de un paso de la muerte a la vida, de un acto de exaltación, de rehabilitación de Dios hacia Jesús y, como consecuencia, de Jesús hacia nosotros por su humanidad. Es de ese estado de ausencia «del que Jesús va a ser "despertado", elevado, resucitado, liberado» ${ }^{40}$. En este sentido, la "teología del sábado», como han considerado algunos autores, no consiste tanto en la entrega del Hijo al Padre, cuanto en que Dios carga sobre sí lo absolutamente anti-divino, la no-comunicación.

En segundo lugar, el paso de Jesús por los infiernos desvela la identidad del hombre otorgada por Dios. La muerte es el «lugar privilegiado para descubrir a alguien, en la medida en que la muerte sella el sentido de una existencia ${ }^{41}$. En la muerte el ser humano tiene la posibilidad de ratificar el itinerario vital que ha desarrollado. Es el momento de la verdad que relaciona pasado y presente. Junto a ello podemos preguntarnos si la identidad de una persona puede circunscribirse únicamente a lo que ella ha logrado en la historia. "¿Es suficiente el tratamiento histórico para comprender siempre cualquier cosa?» ${ }^{42}$. ¿Es la «identidad histórica» la única que puede nombrar a una persona? ¿Acaso no somos también lo que llegamos a ser y no sólo lo que la historia nos permitió alcanzar? La perspectiva teológica de la muerte nos hace ver las cosas de otra manera. Aquello que nos sucede después de la muerte forma también parte de nuestra identidad y nuestra responsabilidad, quizá, no esté ausente de ello. La resurrección aporta esta novedad al ser humano al abrir la posibilidad a una nueva vida (zoé) relacionando pasado, presente y futuro. No como respuesta a nuestros deseos, no como simple continuidad de lo que somos, sino como un nuevo comienzo, una nueva oportunidad de responder a la única vocación del hombre y a la única llamada de Dios, ofrecida desde el origen, a compartir su vida con él. En cierto modo «somos nosotros mismos, con todo lo que hayamos sido, hecho y amado, los que volveremos a encontrarnos en esta segunda vocación» ${ }^{43}$.

\footnotetext{
${ }^{40}$ Le Christ, 171-172/182-183.

41 Ibid., 159/169.

${ }^{42}$ Ibid., 56/60.

43 La Destinée, $76 / 78$.
} 
Así, se revela la identidad del hombre ante la muerte como capax resurrectionis. Su destino obligado no es la muerte, pues es capaz de alcanzar el mismo destino de Jesús ${ }^{44}$.

«La resurrección de Jesús y la de aquellos a quienes él aporta salvación coinciden (co-incidere, caer al mismo tiempo, llegar juntos). Jesús no es sólo el resucitado (resuscitatus), sino también y al mismo tiempo el resucitador (resuscitans, participio activo). El destino personal de Jesús y la salvación de los salvados coinciden. ¿"No era necesario" (Lc 24, 26) que se nos mostrase que el mismo Cristo había sido liberado de los infiernos (Hch 2, 24), para que pudiera salvar a los otros?» $\$$.

Así es como se muestra la respuesta de Dios ante la muerte. La resurrección remodela y reorienta a sus criaturas y, como prolongación, a todo lo creado. Si el ser humano pereciera con la muerte, ¿hasta qué punto quedaría salvado y justificado el Dios que permite tal hecho? El amor de Dios es tan fuerte e ilimitado que no lo rompe ni la muerte y es tan desbordante que, en su victoria, arrastra hacia la Vida a quienes se alejaron de ella. Su combate inexcusable es agónico, difícil, fatigoso. $\mathrm{Ni}$ siquiera el paso de Jesús, según la tradición que estamos siguiendo, fue instantáneo. Su lucha contra el dominio del mal continuó después de su vida terrena, expresión del amor predicado y vivido en su existencia, y ahora llevado a plenitud ${ }^{46}$. ¿Estamos ya irremediablemente sujetos al dominio de la muerte? ¿Nos encontramos solos y sin salidas conceptuales, verificadas por la experiencia de la fe?

\subsubsection{El pecado original}

De manera semejante a la elección del tema del descenso al sheol para describir la significación de la resurrección, Gesché utiliza «la doctrina cristiana más abrupta, la más discutida ${ }^{47}$, para ofrecer una respuesta cristiana al problema del mal: el pecado original. Con su profundización, y una vez situada la función de Dios en el combate contra el mal, querrá, en primer lugar, clarificar la naturaleza de las cosas y señalar, después, la parte de responsabilidad que el hombre tiene en este drama, con la clara

\footnotetext{
${ }^{44}$ Cf. Le Christ, 192/204.

45 Le Christ, 189/200.

${ }^{46}$ Cf. Ibid., 185-189/196-199.

${ }^{47}$ Le mal, 102/104.
} 
intención de liberarlo de la excesiva culpabilidad que, en ocasiones, ha llevado en soledad sobre sus espaldas ${ }^{48}$.

En contraposición a las cosmogonías contextualizadas en la llamada «media luna fértil», la reflejada en la Escritura, afirma la bondad de la creación, como recuerda nuestro autor fuera de Dieu pour penser:

«La palabra del Génesis sobre la belleza y la bondad del mundo es un grito de admiración por la creación y, sobre todo, a los seres humanos. Nosotros no alabamos a Dios, encomiamos la creación. Dios mismo la elogió. Dios también está sorprendido por el bien ${ }^{49}$.

El mal, según nuestra visión de las cosas, ni pertenece a la naturaleza de la creación, ni es voluntad de Dios; es un accidente, una desgracia. Ahí situado, Gesché señalará la tarea fundamental que hay que emprender contra él: combatirlo. Pues, existiendo una precedencia del bien y una finalidad creativa en la creación por el designio divino, el mal se descubre como irracional — carente de razón que lo inaugure- y como un contra-destino. Por ello no debe tener la última palabra.

De igual manera, la Escritura subraya la bondad natural del hombre, en primer lugar, por ser hechura de Dios (cf. Gn 1-2) y, en segundo, porque su actuación respecto al mal fue un acto de consentimiento (cf. Gn 3,6). El relato bíblico no sitúa el origen del mal en el ser humano, ni siquiera en su asentimiento, sino en algo exterior a él —expresado simbólicamente en la serpiente- del que el hombre fue víctima. Estas clarificaciones son fundamentales para quitar peso a la excesiva culpabilización que en ocasiones recae sobre el ser humano. Lo que no excluye una reflexión ponderada de la responsabilidad del hombre en este drama ${ }^{50}$.

Lo cierto, junto a lo dicho, es que el hombre consintió al contra-destino propuesto por la serpiente. La finalidad propuesta bajo forma de bien — «seréis como Dios» $(\mathrm{Gn} 3,5)$ — era en el fondo la concreción del pecado y del error, pues al pretender alcanzar su vocación por los medios erróneos, mediante el árbol del conocimiento del bien y del mal (cf. Gn 2,9; 3,5) y no mediante el árbol de la vida (cf. Gn 2,9; 3,22), el ser humano se distanció de ella ${ }^{51}$. Muestra de ello son las continuas complicidades que hoy día se siguen dando entre el mal y el ser humano. Este consentimiento es lo

\footnotetext{
48 Cf. Le mal, 15-44/19-47, 46-99/49-102.

49 A. Gesché. Le mal et la lumiere. Paris: Cerf, 2003, 51.

50 Cf. Le mal, 105-109/107-111.

51 Cf. La Destinée, 80/82.
} 
que la tradición cristiana ha cifrado como pecado original. «La doctrina del pecado original no es tanto buscar el origen del mal (unde malum) en el sentido de que el mal tiene un origen y, por tanto, un final ${ }^{52}$, sino que pone de manifiesto, fundamentalmente, dos aspectos:

En primer lugar, que en el combate contra el mal no estamos solos. El pecado original puede ser leído como una expresión de la solidaridad humana. Hay que rememorar aquí la idea bíblica de la «personalidad corporativa». Lo que le ocurre a una persona de un linaje concierne a la totalidad, como si los llevara a todos dentro de sí. En nuestro caso, Adán es la persona que la Escritura señala, de manera etiológica, como portadora de toda su descendencia. Así, todo el género humano está implicado en las consecuencias de lo obrado por él. Es decir, en la respuesta que deba dar al problema del mal. Esto libera al hombre concreto de llevar una pesada carga que sobrepasa sus fuerzas. «El hombre no está desamparado en la soledad terrible de un mal que haya cometido, en la responsabilidad sola y terrible de una culpabilidad, cuyos hilos estuvieran todos ellos en sus manos ${ }^{53}$. Esta visión de las cosas — del linaje, de la solidaridad, etc.- - permitió a Pablo designar a Cristo como el segundo (cf. Rom 5,14) o el último Adán (cf. 1Cor 15,45). Él, por su singular humanidad, lleva dentro de sí a todo el género humano y, por lo obrado en él, se reorienta el consentimiento del hombre a Dios y se restaura el error de destino y de finalidades cometido en el origen ${ }^{54}$.

El segundo aspecto relevante de la doctrina del pecado original es que la responsabilidad del hombre tiene un adjetivo sustantivado: es una responsabilidad de libertad. La palabra «consentimiento» expresa esta noción. El hombre que consiente no tiene por qué estar obligado a hacerlo. Denota una decisión, un acto de libertad que desvela cierto dominio sobre el mal, pues se podría no haber elegido. "Efectivamente, el "tú eres culpable" (“Caín, ¿qué has hecho con tu hermano?”), el "tú has pecado", significa: "habrías podido no pecar". La acusación es al mismo tiempo la afirmación: "Eres capaz de no hacerlo" ${ }^{55}$.

De esta manera se manifiesta la capacidad salvífica de nuestro concepto. Tanto su consecuencia solidaria como el desvelamiento poderoso de la

\footnotetext{
52 A. Gesché. Le mal et la lumiere. o. c. 79.

53 Le mal, 110/112.

${ }^{54}$ Cf. Ibid., 61-62/64-66; La Destinée, 79-81/81-83.

55 Le mal, 111/113.
} 
libertad son una manera de decir que el mal no tiene la última palabra, que nunca hay nada definitivamente perdido, que las cosas pueden ser como eran antes ${ }^{56}$. Es cierto que la propuesta cristiana de la salvación no tiene por qué introducir la idea de mal o de pecado, pero lo cierto es que el mal existe y que la salvación toma este colorido. Con todo, y sin ver absolutamente nada positivo en el mal, ¿ no añade su experiencia un plus que hace caer en la cuenta, más si cabe, del exceso de bien de la Creación y de las criaturas? ¿No desvela, sin pretenderlo, la sobreabundancia, la donación saturada, de un Dios que brinda todas las posibilidades para deponer al mal?

\subsubsection{La eternidad}

Ante el último de los límites señalados por Gesché, la fatalidad, ¿qué podrá aportar el logos de la fe? Parece, en un primer momento, que el discurso sobre la salvación en este ámbito se presenta más difuso, en comparación con el de la muerte o el mal. De las constricciones espaciotemporales nadie se puede librar, tan sólo a costa de la propia vida. La cuestión es, en primer lugar, cómo lograr que esos condicionamientos no ejerzan un dominio que no les corresponde y, en segundo, cómo liberar al hombre del discurrir del tiempo que, en ocasiones, se muestra inexorable, denso, aplomado. La tarea, aunque difícil, tiene el aliento de aquellos pensadores que al margen de la fe han afirmado que el cristianismo ha «desfatalizado la historia ${ }^{57}$, la ha liberado del destino trágico de la concepción griega del fatum.

La fe cristiana propone como elemento liberador del tiempo la eternidad. Es el horizonte capaz de tensar el presente y hacerlo fecundo sin renunciar a él. En ocasiones, tal presente, con todo lo que trae consigo, es visto como una cárcel para la auténtica identidad y libertad de la persona. Rezuman aquí concepciones gnósticas de origen platónico cuyo deseo consistía en liberar a la parte más noble del hombre —el alma-, de la cárcel del cuerpo, en la que se padecían todos los condicionamientos de la existencia. Así, se deseaba la inmortalidad como el estado de la auténtica naturaleza del alma, inalcanzable desde la reclusión del cuerpo caduco ${ }^{58}$.

${ }^{56}$ Cf. Ibid., 113/115.

57 La Destinée, 37/39, 163/165; Le Christ, 44/48; Le Sens, 104/118, 115/129.

58 Cf. La Destinée, 94/96. 
El horizonte cristiano de esta manera de entender las cosas excede con creces esta cosmovisión, proponiendo la eternidad como auténtico destino para el hombre. Analizando y comparando ambos conceptos -inmortalidad-eternidad - podemos constatar la riqueza y la novedad del pensamiento cristiano sobre el «techo del tiempo».

La inmortalidad no es más que una continuación de nuestra existencia; ella por sí misma no constituye un proyecto, a lo sumo es una liberalización despectiva del tiempo. Desde ella, la muerte pierde significado; es tan sólo un paso por el que el hombre desfila, como sin saberlo. Para la inmortalidad, el motivo primero de preocupación es que el hombre se reencuentre a sí mismo, salvando así su pasado. La eternidad, en cambio, brinda al hombre una situación totalmente nueva ofreciéndole un nuevo proyecto, como es la proposición de un destino más allá del paso necesario por la muerte. Es un despliegue de nuevas posibilidades, nacidas del valorado acontecimiento del fin de la vida, donde lo más importante es el reencuentro con Dios, salvando así no sólo el pasado, al reasumir la propia historia, sino también el futuro, lo que está por venir desde la profundidad divina ${ }^{59}$.

La eternidad no es, en absoluto, un concepto analgésico que haga remitir los efectos del tiempo, sino que se muestra como un horizonte de comprensión efectivo. Da sentido al tiempo presente. No lo devalúa ni lo desprecia, sino que lo tensa llevando sus posibilidades hasta el exceso. El tiempo para los cristianos es una bendición divina, prolongando así uno de los mejores aspectos del pensamiento veterotestamentario. En él, el hombre tiene la posibilidad, como ofrecimiento y como don, de ser «bien dicho», de recibir la bendición, el favor de Dios, al ser el tiempo de la realización concreta de su destino: compartir la vida divina. De esta manera, el tiempo marcado por nuestra vida biológica no es contrario ni contradictorio respecto del tiempo divino, pues resulta accesible al hombre. En él no hay pérdida de identidad, ni renuncia a la propia historia - a diferencia de lo que propone el pensamiento oriental-. Incluso, en la consumación del tiempo, como dice el Apocalipsis: «Verán su rostro y llevarán su nombre en la frente» $(22,4)$. Se trata de una relación, no de una fusión. Es conocida la significación de la «teología del nombre» que indica la identidad de la persona, toda su historia, todo lo que es, ha sido y será. La totalidad de la persona, sin exclusión de nada de lo vivido, será puesta de manifiesto — «alumbrará» dice el siguiente versículo—, por el

\footnotetext{
${ }^{59}$ Cf. Ibid., 96-99/98-101.
} 
Dios que ha decidido compartir su vida, su temporalidad —aiôn-con el hombre.

Pero incluso, sin tener que llegar a la consumación, el tiempo de la vida biológica y el tiempo divino no se sitúan como yuxtapuestos, sino que el primero es continuamente seccionado y abierto a su futuro, por una modalidad cristiana del segundo: el kairós. Este tiempo, que nuestro autor traduce como «instante ${ }^{60}$, es la visitación del tiempo divino por el que la eternidad se inserta en nuestro tiempo. Es el tiempo propicio, favorable, oportuno, el tiempo de la salvación aquí presente entre nosotros, el tiempo de la encarnación, de la glorificación y de la parusía. "Nuestro "ahora" es un tiempo que ya tiene un valor de eternidad y de destino ${ }^{61}$. Por eso, el destino del hombre también se juega en este mundo. No como simple prolegómeno, sino como realización proléptica. La vida en nuestra tierra, en su cotidianidad, es objeto de ese destino al que estamos llamados. Lejos queda ya la pretensión dominadora del destino trágico, pues ella deberá batirse con la eternidad presente en el drama por la completa salvación ${ }^{62}$.

De esta manera es como Gesché muestra que el tiempo no tiene la última palabra y cómo debe remitirse a la eternidad que le da su significado último, la hondura de cada uno de sus instantes y el destino de su devenir. Temporalidad y eternidad no contrapuestas ni yuxtapuestas, sino intrínsecamente relacionadas: «Dios posee al tiempo en plenitud y nosotros poseemos ya algo de eternidad, no para destruir nuestro tiempo, sino para decir su sentido infinito» ${ }^{63}$.

\section{UNA CUESTIÓN RADICAL: ¿CUÁL ES EL FUNDAMENTO?}

Por la resurrección, la doctrina del pecado original y la eternidad, parece que los límites que el ser humano encuentra en su existencia se tornan, quizá tan sólo y en el fondo, como límites conceptuales y no como auténticos muros infranqueables ante los que claudicar en la búsqueda y consecución de su destino. Es cierto que no dejan de estar siempre ahí, expectantes,

\footnotetext{
${ }^{60}$ Cf. La Destinée, $110 / 112$.

61 La Destinée, 110/112; cf. L'homme, 116-117/113.

62 Cf. Le Cosmos, 188/307.

63 La Destinée, 112/114.
} 
amenazantes, emboscados, con la pretensión de ejercer su dominio, pero, desde la lógica de la fe, Gesché ha mostrado de manera comprensible la plausibilidad de que esos límites pueden convertirse en encrucijadas, en hitos donde la horizontalidad de nuestra inmanencia puede ser quebrada y abierta por la verticalidad de la trascendencia. Es en esos profundos interrogantes - la muerte, el mal y la fatalidad - donde el hombre puede sumirse en la estrechez de su horizonte o puede elevarse hacia los confines de la trascendencia. Es en esas encrucijadas donde sus capacidades pueden ser elevadas, tensionadas, atraídas; donde se muestra su naturaleza inmanente pero radicalmente difractada hacia la trascendencia.

Ahora bien, en este itinerario ad Deum conviene no ir demasiado deprisa, incluso habría que interrogarse si, en el fondo, no deberíamos buscar o constatar un itinerario ad hominem, pues, vistas así las cosas, surge la pregunta por el fundamento radical de tal capacidad otorgada al ser humano. ¿Son tan sólo una serie de conceptos que, con argucias y sutilezas argumentales, pueden dar una solución a lo que no la tiene? ¿Basta con apropiárselos nocionalmente y saberlos exponer llegado el momento? ¿Dónde queda el Dios trinitario y la función soteriológica específica de cada una de las personas divinas si parece que el ser humano, por su raciocinio, puede encontrar su propio cumplimiento? ¿Puede que el hombre, en cuanto criatura, lleve inscrito su designio y las capacidades para lograrlo? ¿Puede que dichas categorías, la percepción de su destino y la capacidad para lograrlo, sean muestra de «algo» que ha sucedido antes; de algo que, motivado extra nos y en virtud de nuestro asentimiento vital, ¿nos capacite radicalmente para lograrlo?

Atisbamos en estas cuestiones el elemento central del cristianismo. La peculiaridad de la experiencia subjetiva provocada por una determinada configuración del Misterio. Y más radicalmente, el nexo fundante de la relación entre Dios y los hombres: el reconocimiento de Jesucristo como único y definitivo mediador de salvación que debe dar cuenta de su estrecha relación con Dios y de las consecuencias de esa relación para toda la humanidad.

\subsection{LA FILIACIÓN: HIJOS EN EL HiJO}

De todos los títulos otorgados a Jesucristo, el de «Hijo de Dios» es el que, según Gesché, puede dar respuesta a estos interrogantes. Respuesta 
no sólo conceptual, al establecer las relaciones entre Dios y Jesús, y entre Dios y los hombres, por medio de Jesús y su Espíritu, sino, también, por ser la expresión de una peculiar experiencia soteriológica. Éste, quizá, sea el punto más problemático, pues el título «Hijo de Dios» parece ser el que ofrece mayores dificultades para ser insertado en el polo subjetivo de la experiencia de fe. ¿Nos encontramos ante una mera especulación? ¿Es el resultado de querer ensalzar excesivamente la persona de Jesús? Otras denominaciones, como Salvador, Cristo, Enviado, parecen ser la manifestación de lo que Jesús ha significado para las primeras comunidades, de lo que experimentaron que Jesús era para ellas. En cambio, referirse a Jesucristo como Hijo de Dios, ¿acaso implica adentrarse en el ámbito de la Filosofía Primera, de la constitución ontológica de Jesús, olvidando la génesis que ha generado su confesión y realizando gratuitamente una concesión demasiado elevada de su persona? Sin embargo, no faltan desarrollos cristológicos en las primeras comunidades que se refieren a Jesucristo con tal denominación; incluso, algunas articulaciones contemporáneas la declaran como categoría suprema. No sólo por su significación ontológica, sino también por las consecuencias que se derivan de ella en la compresión del ser humano, del creyente y de la Iglesia. Para la cuestión que ahora nos ocupa es de capital importancia, pues con dicha categoría no sólo designamos a Jesús, sino también a los cristianos, encontrando en ella, como tratará de mostrar Gesché, el fundamento soteriológico requerido, el nexo sólido entre revelación y salvación.

Si bien la estrecha relación entre Dios y Jesucristo, que implica el título «Hijo de Dios», es algo que fue clarificado en el largo proceso de los cinco primeros concilios ecuménicos, la génesis de tal consideración y la significación para nosotros como hijos adoptivos de Dios es lo que Gesché tratará de profundizar formulando la hipótesis de una particular experiencia: «sería primero la [identificación] del cristiano [como hijo], desde donde quedaría revelada y manifestada la condición propia de Jesús ${ }^{64}$. Para ello centrará su búsqueda en el corpus paulino.

Cuando Pablo habla de la experiencia religiosa fundante de los cristianos lo hace en términos de filiación. Desde esta categoría se pone de manifiesto la relevancia de cada una de las personas trinitarias y la novedad de la experiencia cristiana. El Espíritu es el que nos constituye en hijos adoptivos (cf. Rom 8,15-16). Por la fe en Cristo Jesús somos hijos de

${ }^{64}$ Le Christ, 196/208. Los corchetes son nuestros. 
Dios (cf. Gál 3,26). Para eso envió el Padre a su Hijo, para que recibiéramos la condición de hijos adoptivos de Dios (cf. Gál 4,5). Podemos decir que en el tema de la filiación Pablo expone su Cur Deus homo: el Verbo se ha encarnado para que el hombre sea constituido en hijo adoptivo de Dios. Ésta parece ser la buena noticia que anunciar. Desde la filiación adoptiva emerge la renovada dignidad del ser humano como criatura libre (cf. Rom 8,21) y destinada a compartir la misma herencia del Hijo (cf. Rom 8,17): la gloria de Dios prometida desde siempre (cf. Gál 3,29; 4,5-7). En el seno de esta experiencia soteriológica, y no desde una especulación cualquiera de tipo helenístico, es desde donde la comunidad hablará de Jesús como Hijo de Dios. Habría, por tanto, una prioridad noética y cronológica —epistemológica, para mayor claridad-, sobre la identificación de Jesús como Hijo, aunque inmediatamente se desvele la prioridad ontológica y teológica de su filiación divina que posibilita y sustenta la nuestra ${ }^{65}$. En este sentido se puede decir que la reflexión fue provocada por una particular experiencia personal de salvación. Esta expresión conviene ser matizada y clarificada, no sólo por el peligro del subjetivismo o de rebajar la experiencia de Dios a la de cualquier otro ámbito de la realidad, sino también para dar cuenta de su alcance con mayor precisión.

Sin duda la palabra «experiencia» es una de las que presentan mayores dificultades para su comprensión, sobre todo en el contexto de nuestro discurso; pues estamos poniendo de manifiesto que el reconocimiento de la filiación de Jesús tiene su inicio en la experiencia de los primeros cristianos como hijos adoptivos. Por este motivo, como señala el teólogo de Lovaina, quizá sería más oportuno hablar de un acontecimiento de revelación, de revelación de nuestra filiación ${ }^{66}$.

En páginas anteriores a las que estamos siguiendo para el presente desarrollo, Gesché se detiene en la semántica del concepto «revelación» ${ }^{67}$. Auxiliado por la psicología y la fenomenología subraya tres aspectos de todo acontecimiento de revelación: la capacidad receptiva del hombre, la exterioridad de tal acontecimiento y la conmoción o conversión que provoca. Así, después de evocar los términos de "pasividad subyugada» (J. Kristeva), «emoción significante» (P. Ricoeur), «emoción punzante»

\footnotetext{
65 Cf. Le Christ, 203/215-216.

${ }^{66}$ Cf. Le Christ, 210/223.

${ }^{67}$ Cf. Ibid., 152ss./162ss.
} 
(C. Lévi-Strauss), dirá: «Yo llamaría "acontecimiento de revelación" a la apertura de un espacio y al brote de un tiempo en el que se descubre una realidad invisible escondida en lo visible» ${ }^{68}$. Esta apertura de un tiempo de descubrimiento se caracterizó, para los primeros cristianos, por una especial relación de libertad con Dios de la que antes no gozaban, semejante a la que Jesús había tenido con su Padre ${ }^{69}$; como si Jesús les hubiera comunicado su propia dignidad y, con ella, la libertad ante todos los obstáculos de la fatalidad que Él había superado: la muerte, el pecado y la ley ${ }^{70}$.

En esta revelación de libertad —referida por nuestro autor como «irrupción $»^{71}$ - es en la que "se encuentra, al momento, la palabra justa para calificar lo que se acaba de revelar» ${ }^{72}$. Pablo encontró en el título «Hijo de Dios» la palabra oportuna para dar cuenta, tanto de la identidad de Jesús, como de la experiencia que padecía y anunciaba. La revelación de su filiación adoptiva sólo pudo darse en cuanto que recibió el Espíritu de adopción (cf. Rom 8,14) que le desveló su verdadera identidad escondida y la de Jesús: era hijo en el Hijo. Por ello el título de «Hijo de Dios» no nació de una especulación helénica de gabinete, sino, en primer lugar, de una experiencia soteriológica por la que los primeros cristianos pudieron reconocerse en la libertad de los hijos de Dios y, por esta libertad, se supieron partícipes de aquél que gozaba de tal relación con Dios y del único que podía otorgarla: Jesucristo. En dicha experiencia constataban que era Jesucristo mismo quien se estaba revelando. Él no era sólo el revelador, sino también lo revelado. Hijos en el Hijo por el que podían clamar ¡Abba! (cf. Rom 8,15). Los efectos experimentados no fueron sino expresión de la acción efectiva de Dios, por su Espíritu, en su Hijo. Por ello, «el Hijo de Dios no es el que los hombres hubieran podido darse, sino aquel que el Padre ha revelado: "Dichoso tú, Simón, hijo de Juan, porque eso no te lo ha revelado ningún mortal, sino mi Padre que está en los cielos" (Mt 16,17)» ${ }^{73}$. De la revelación del Padre a Simón surgió

${ }^{68}$ Le Christ, 156/166. En otro lugar dirá: «Revelación, es decir, advenimiento de sentido, proceso en el que nosotros no aportamos nada y, sin embargo, rendimos testimonio de aquello que nos ha sido dado» (Le Sens, 14/24).

${ }^{69}$ Cf. Le Christ, $214 / 227$.

70 Cf. Ibid., 210-211/223-224; La Destinée, 64-65/66-67.

${ }^{71}$ Le Christ, 153/163, 155/165.

72 Ibid., 214/228.

73 Ibid., 208/221. 
la confesión de la filiación de Jesús y, por ella, éste desveló la verdadera identidad de Simón: «Y yo a mi vez te digo que tú eres Pedro» (Mt 16,18).

Este último versículo abre la última cuestión a tratar. La filiación adoptiva, como acabamos de ver, no sólo da un fundamento sólido a la salvación, mostrando el nexo consistente que da cuenta de la constitución ontológica de Jesucristo y de la relación entre Trinidad e historia, sino que también ensancha el horizonte de la identidad del creyente y delinea el camino a seguir para su cumplimiento. Jesús, al donar una nueva identidad a Pedro, le da un destino y, con él, un nuevo proyecto. Parece que, tras la confesión de Jesús como Hijo de Dios, Él confiesa nuestra filiación adoptiva; recibimos la confesión de Dios sobre nuestra identidad y, en ella, su confianza y su elección sobre el ser humano que lo confiesa ${ }^{74}$. Ahora bien, la identidad ofrecida y el destino propuesto, aunque gratuitos, no se dan de manera automática. El don es para ser acogido, querido, preparado. «El que te creó sin ti no te salvará sin ti ${ }^{75}$, recuerda Gesché citando no pocas veces a san Agustín, indicando con ello que el ser humano debe emprender un itinerario hacia su cumplimiento, hacia su salvación, con lo que ello implica: voluntad, decisión, elección, tiempo, concreción. Itinerario ciertamente iniciado por Dios, indicado por él, acompañado por él, pero recorrido por el hombre. Como bellamente señala nuestro autor:

«[...] el hombre es como un texto. Al principio, un manuscrito, pues está hecho ya, en parte, de una escritura que le precede y que debe aprender a leer para descifrarse. [...] Luego un pergamino, pues el hombre, pese a ser por fortuna inacabado, debe escribir él mismo - pastor de su ser-, sobre la página todavía virgen, el texto de su propio destino. Finalmente, un jeroglífico, pues está escrito y debe seguir escribiéndose con caracteres sagrados. "Res sacra homo" ${ }^{76}$.

\section{MÁS ALLÁ DEL HORIZONTE DE LA EXPERIENCIA}

El destino ofrecido desde la experiencia de la filiación adoptiva es la salvación. En sí misma, la filiación adoptiva sugiere ya un origen y la pertenencia al ámbito divino, de igual modo que pone de manifiesto la

\footnotetext{
${ }^{74}$ Cf. Le Sens, 75-78/86-90. Sobre la construcción de la identidad, en la misma dirección, cf. Le Christ, 87-127/80-135.

${ }^{75}$ Le Sens, 75/87; L'homme, 83/81; Dieu, 157/142; Le Cosmos, 192/311.

76 L'homme, 8/10.
} 
función mediadora de Jesucristo y de su Espíritu. Para articular estas tres dimensiones de la salvación, Gesché señalará el destino ofrecido al hombre con la categoría de «divinización». De entre las múltiples categorías que se han utilizado en la historia de la teología para referirse a tal acontecimiento (redención, remisión, rescate, liberación, etc.), nuestro autor tiene especial querencia por ella, pues tiene la virtualidad de indicar con claridad tanto el aspecto positivo de la salvación ${ }^{77}$, como la realidad a la que apuntan otras categorías ${ }^{78}$. Con todo, Gesché indica veladamente la posible torpeza de este término ${ }^{79}$, expuesta por Hans Küng en Ser Cristiano: “¿Qué hombre razonable quiere hoy llegar a ser Dios?» ${ }^{80}$. Parece, según esta observación, que la divinización implica un proceso por el cual dejamos de ser hombres renunciando a aquello que somos y una evasión del lugar donde existimos. ¿Será acaso un lujo, una distracción metafísica que nos aparte de las urgencias y prioridades de este mundo? Veremos que, articulada de manera acertada, no tiene por qué adolecer por estas cuestiones.

\subsection{La SALVACIÓN COMO DIVINIZACIÓN}

Theopoiesis y theosis son los términos con los que Gesché hace referencia a la divinización ${ }^{81}$. Con ellos quiere recoger la perspectiva desarrollada fundamentalmente por los Padres Griegos y también por el pensamiento franciscano para hablar de la salvación ${ }^{82}$. Esta categoría tiene la virtud de señalar la estrecha relación entre protología y escatología, aspectos de especial interés para nuestro autor y cruciales en Dieu pour penser, a la vez que hace emerger como cumplimiento supremo el acontecimiento cristológico.

Divinización remite al designio original del ser humano descrito en la Escritura, por eso fue una de las categorías más desarrolladas en la patrística: «al ser creado a imagen y semejanza de Dios, el hombre recibió en la creación el espíritu de Dios (el pneuma toû Theoû) como diferencia

77 Cf. La Destinée, 58/60.

78 Cf. Le Christ, 209/222.

79 Cf. La Destinée, 86/88.

80 H. Küng. Ser Cristiano. Madrid: Cristiandad, 1977, 562.

81 Cf. Le Christ, 208/221; La Destinée, 58/60, 86/88.

82 Cf. La Destinée, 58/60; Le Christ, 209/222. 
formal respecto de las demás criaturas animadas (que han recibido solamente una psyché)»» ${ }^{83}$. Con esta consideración, ampliamente desarrollada en sus escritos, Gesché quiere mostrar la estrecha relación en el origen entre Dios y el hombre, y las consecuencias que de ella se siguen ${ }^{84}$.

«Al principio creó Dios el cielo y la tierra» $(\mathrm{Gn} 1,1)$. Pese a ser distinto, Dios no plantea su relación con el hombre desde la distancia, sino desde la libertad y el don al ofrecerle todos los medios para la estrecha convivencia con él. Dios crea un espacio de relación ordenado, armónico, fruto de un acto libre de decisión que genera una obra libre y distinta de sí. «La libertad arranca desde el zócalo de la creación "desde" antes que emerja el hombre» ${ }^{85}$. Ella es la que preside la razón de la creación posibilitando el libre desarrollo de cuanto acontece en ella. Por ello, la libertad no es algo que arrebatar a la divinidad, sino que pertenece a la misma creación y a sus criaturas desde la libertad exuberante de Dios.

«Hagamos a los hombres a nuestra imagen y semejanza» $(\mathrm{Gn} 1,26)$. El ser humano participa, por su misma naturaleza teo-lógica, de ese mismo ámbito de libertad, de decisión e invención en todo cuanto le ha sido otorgado. El hecho de crear, por otra parte, remite a la alteridad, a la diferencia, a lo otro, llamando siempre a respetar la distancia inaugural para no convertirse en alienación. Libertad y alteridad remiten a unmás-allá-de-sí que no se puede dominar ni controlar, sino que hay que respetar para que siga existiendo. La alteridad, lo distinto de sí, es por tanto una realidad fundante y conservadora; funda algo distinto de sí en la relación y lo conserva en la diferencia.

Estas consideraciones indican, ya desde los orígenes, un modo de ser y de relacionarse específico para el ser humano. Así como ha obrado Dios, debe hacer el hombre. No como el mandato de una pesada carga que sobrepasa sus fuerzas, sino como el ofrecimiento y la oportunidad de participar, «a imagen y semejanza», del mismo modo de hacer y relacionarse que Dios.

Vista desde la perspectiva del origen, la divinización tiene poco que ver con la consideración de H. Küng. No consiste en llegar a ser Dios renunciando a ser hombre, sino en llegar a «ser-como» él manteniendo la

\footnotetext{
83 La Destinée, 81/83.

${ }_{84}$ Cf. Le Sens, 19-24/31-34.

${ }^{85}$ L'homme, 74/73.
} 
propia identidad (alteridad) ${ }^{86}$. Dios no creó algo igual a él, sino al hombre semejante a él, como él, a imagen suya; en concreto, según el desarrollo teológico posterior, a imagen de su Hijo (cf. Col 1,16). Este «ser-como» es posibilidad para el ser humano; por él tiene la capacidad de obrar con la libertad otorgada por Dios, pero siempre en la diferencia. Su posibilidad no consiste en ser Dios, sino en ejercer su libertad co-creadora en el espacio donado para su realización y en orden a una relación con su creador semejante a la que gozaba en el principio. Es, por tanto, una llamada a poner de manifiesto la trascendencia en todo aquello que es obra de su libre voluntad en orden a su Creador. Es una continua indicación al destino y al sentido último de su existencia en todo cuanto realiza y proyecta. Es manifestación de la profundidad ética en las relaciones que establece con sus semejantes. Por ello, desde la perspectiva cristiana, no existe ninguna disyuntiva entre humanización y divinización, su relación es coincidente en la existencia del hombre y su realización es coextensiva: cuanto más plenamente se realiza el ser humano, más cerca está del ámbito divino, más se asemeja a la relación originaria entre él y Dios. Por esto, este "ser-como» desvela, junto al origen, una tarea y un destino. Lo que nos lleva al segundo aspecto a considerar.

El destino, tema al que dedica el quinto volumen de Dieu pour penser, pone de manifiesto el carácter trascendente del hombre. Evoca las finalidades, las esperanzas, el cumplimiento del deseo último y la dinámica de la acción humana (Blondel). Una continua deixis hacia el magis de donde nos encontramos y hacia el exceso de lo fenoménico. «Se trata, todavía y para siempre, del "para qué" ${ }^{87}$. Esta pregunta sólo puede ser comprendida en su ultimidad desde la teología y sólo su gramática puede descifrarla. La ciencia se preocupa por saber lo que son las cosas, la filosofía por el sentido que tienen, la teología en cambio vela por su destino, llevando las cosas mismas hasta el exceso que sólo ella puede indicar: Dios mismo ${ }^{88}$. Por eso, quizá, el concepto de divinización se muestra como el más original y el más adecuado para sugerir la solución al eterno, y nunca mejor dicho, interrogante del deseo. ¿Qué desea el hombre? ¿Qué espera? ¿Cuál es el «hacia dónde» de su experiencia trascendental?

\footnotetext{
${ }^{86}$ Cf. Le Sens, 173/188.

87 Le Sens, 83/96.

88 Cf. Ibid., 84-86/97-98.
} 
«La idea de que existe una presencia de algo que es más que lo inmediato, aunque sea una presencia vacilante, extremadamente discreta, pero siempre, en todo caso, más o menos deseada o codiciada, apetecida o presentida, incluso para aquellos que han optado por la idea de que eso es sólo una ilusión. Pero todos han pensado siempre en ello» ${ }^{89}$.

Tal idea ha sido valientemente proclamada e intrépidamente identificada desde la fe. En su vacilación, el logos de la fe confiesa que esa huella en negativo inscrita en la profundidad del hombre, esa presencia elusiva en su temporalidad es, a su vez, lo más excesivo, lo más elevado capaz de responder al deseo de la condición y la felicidad divinas que anhela ${ }^{90}$; no desde la inmanencia de su materialidad, sino en ella y desde quien es puro exceso y donación. «Pero tú eras más íntimo que mi propia intimidad y más alto que lo más alto de mi ser ${ }^{91}$, decía Agustín constatando ese sentirse tensionado y reclamado por Dios a ser lo que realmente era y trataba de eludir. Por ello, la divinización, el ser-como Dios, el situarse en su ámbito, no es fruto del esfuerzo y la voluntad humanas, sino que, germinando en su interior, se descubre como algo que le viene de fuera, que le visita desde la exterioridad y que sólo puede llegar a su término por el ejercicio efectivo de la pasividad del hombre: dejarse hacer y modelar como en el origen, para recuperar y llevar a plenitud su imagen original.

Templo del Espíritu desde el bautismo, el cristiano tiene como finalidad, como telos de su existencia, convertirse en morada de Dios, en dejarse pasivamente habitar por él y en revertir activamente su presencia, excesiva y saturada, en la totalidad de su vida; en sus opciones y proyectos, en su intimidad y sus relaciones. Hay, por ello, una capacidad inscrita - la teología hablará de la inhabitación del Espíritu— para ser capaces de Dios ${ }^{92}$. No hay, por tanto, un cortocircuito que deja al hombre sólo con sus deseos, perdido y arrojado en el mundo, sino una realidad fecundada por el germen divino que se realiza lentamente, en medio de fracasos, esclavitudes y desesperanzas; una capacidad del hombre a realizase como hijo en el Hijo (cf. Jn 1,12); un derecho a llegar a descubrir

\footnotetext{
${ }^{89}$ Le Sens, 86/99.

90 Cf. L'homme, 141/139.

91 Agustín de Hipona. Confesiones, III, 6, 11 (Trad. J. Cosgaya. Madrid: BACMinor, 2007, 87). Cf. Le Sens, 86/98.

92 Cf. L'homme, 107-109/105-106.
} 
la hondura de su filiación adoptiva y su extensión en la fraternidad entre los hombres ${ }^{93}$ :

«Un proyecto divino que, sin aislarle del mundo, que es el suyo ("el cielo pertenece al Dios del cielo; la tierra la ha dado a los hombres", Sal 113,16), pide al hombre que intente sobrepasarse sin cesar a sí mismo, con el infinito como horizonte, "con el futuro como norte" (Celan) ${ }^{94}$.

En definitiva, una estrecha relación entre origen, destino y sentido de la existencia. Por ello, debemos dar un paso desde la comprensión de nuestro autor. Expuestos los fundamentos teológicos de la identidad y la ultimidad del ser humano — protología, cristología y escatología-, quedan por indicar los ámbitos de realización concreta de su identidad y su vocación; los lugares donde se da y puede ser afirmado este destino teologal ofrecido.

\subsection{La SALVACión EN LOS LUGARES DE LA REVELACIÓN}

Uno de los riesgos al mostrar los fundamentos de todo concepto teológico consiste en que, después de ser articulados en su propia coherencia interna y de haber mostrado la plausibilidad externa mediante el auxilio o las consonancias con otros saberes, queden sin suelo firme y sin espacio concreto para su verificación. Quizá esto nos pueda pasar al hablar de la salvación. Que quedemos sin suelo firme donde pisar y sin espacio concreto donde indicar la posible realización de dicho acontecimiento. Bien es cierto que siempre debemos tener presente que la salvación es algo dado, viene de Dios y sólo Él la puede otorgar. Tampoco se puede olvidar la llamada «reserva escatológica» (E. Peterson), que nos recuerda ese intervalo de discreción entre la facticidad de la historia y su consumación. Pero, después de haber apuntado hacia el cielo de la experiencia y la tensión hacía él, queda pendiente el aquí y el ahora, mostrándolo, no sólo en la lectura teológica de la historia, sino, sobre todo, en su efectividad presente. Ésta es la pretensión de fondo en el último volumen de Dieu pour penser: Le Sens.

\footnotetext{
93 Cf. Le Cosmos, 104/231-232.
}

94 Le Sens, 22-23/33. 
La cuestión del sentido, evidentemente, no pertenece al exclusivo ámbito de la teología, de igual modo que la teología tampoco puede poner a Dios al servicio del sentido, pues supondría caer en la idolatría y en el pragmatismo de la fe. Pero, como en otras ocasiones, la teología sí puede aportar su propio logos y, en esta aportación, verse enriquecida. El sentido, sin saber muy bien cómo, pertenece al ámbito de la existencia y es constatable en ella misma. Por eso, quizá pueda aportar ese suelo concreto que facilite constatar la experiencia de que "ya» somos salvados. «Yo creería en vuestro Dios si tuvierais cara de personas salvadas», decía Nietzsche reclamando lo mismo que nosotros ahora ${ }^{95}$.

El sentido emerge en las cosas mismas poniendo de manifiesto su consistencia y haciendo descubrir espacios que, de otra forma, resultarían siempre velados. Decir " "esto" tiene sentido", es percibir la consistencia de lo dado y, en ello, una novedad que se abre paso gratuitamente en la positividad. Esta «emergencia constatada» en el sentido tiene grandes convergencias con la palabra "revelación», tan propia y específica del lenguaje religioso. Aunque su uso se haya extendido con el riesgo de perder su origen, sigue teniendo una carga semántica específica y, lo que ahora nos interesa, sigue recordándonos que somos sujetos pasivos capaces de ser visitados por una alteridad ${ }^{96}$.

La novedad notificada en la revelación cristiana es la salvación. Ésta es el efecto que produce aquélla. Como dijo el Concilio Vaticano II, «quiso Dios, con su bondad y sabiduría, revelarse a Sí mismo y manifestar el misterio de su voluntad: por Cristo la Palabra hecha carne, y con el Espíritu Santo, pueden los hombres llegar hasta el Padre y participar de su naturaleza divina» (DV 2). Así es como revelación y salvación se intersignifican. El Dios que se revela se da a sí mismo, y con ello desvela su voluntad salvífica sobre el hombre, «ya» le hace participar del «cielo» en su experiencia.

Por la estrecha relación entre salvación y revelación (ad intra) y la de ésta última con el sentido (ad extra), vamos a tratar de extraer el núcleo común de los lugares donde emerge el sentido, mostrando cómo, desde el logos de la fe, se desvelan como lugares de salvación. Algunos ya han sido mencionados - la libertad, la identidad, el destino-, por eso, ahora nos detendremos en la fenomenicidad de la salvación en dichos lugares

\footnotetext{
95 Cf. La Destinée, 62.

96 Cf. Le Sens, 15/25.
} 
y no tanto en su constatación o fundamentación teológica. Es decir, en cómo se muestra su aparecer en determinados ámbitos de la realidad y se ofrece a nuestra aprehensión.

«La fenomenología insiste mucho en este tema, como empezó a mostrarlo Husserl cuando hablaba de sus famosas "síntesis pasivas". $\mathrm{Al}$ comienzo, antes de que nuestra conciencia y sus intencionalidades actúen sobre ellas, existen unas "impresiones originarias" (Ur-Impression) que chocan con nosotros y que influyen en la construcción de nuestro ser, de manera que podemos hablar de ellas como de donaciones que, en cierto sentido, nos preceden y que nosotros no hemos buscado» ${ }^{97}$.

Estas primeras impresiones originarias constituyen el punto inicial, en nuestra experiencia, de la salvación. Son el fundamento subjetivo para construir la autoconciencia de ser salvados, pues, a partir de ellas, con las especificidades del Misterio cristiano y sus categorías, se formulan y articulan dichos eventos en el todo orgánico de la fe.

La fenomenicidad de estas impresiones originarias está de fondo cada vez que Gesché hace referencia al exceso. La capacidad y la necesidad para padecerlo constituyen una de las constantes en toda su obra. «G. Steiner [comenta Gesché] descubría la visita hecha al hombre por una presencia y un don que le vienen de fuera y que, sin embargo, le son constitutivos ${ }^{{ }^{98}}$. Antes que nada, casi como un prius ontológico, se constata la capacidad de ser excedidos en todos los órdenes - la identidad, la libertad, el destino, etc.- - Ella es la condición de posibilidad para que el exceso sea considerado como propio; no como posesión, sino como pertenencia y necesidad - el exceso forma parte de cada uno y cuando esto no es así, se percibe la necesidad o el deseo de ser visitado y alterado por el exceso- Esto es lo expresado con la huida de la tautología de la inmanencia que tanto preocupa a Gesché, ¿o acaso puede afirmarse que la inmanencia sea para el hombre la gracia suprema? ${ }^{99}$. No para nuestro autor. Por eso se entiende todo el esfuerzo en mostrar, desde la filosofía judía y la fenomenología literaria, esta realidad profunda de la fe ${ }^{100}$. De

97 Le Sens, 14/24.

98 Le Sens, 109/124.

99 Cf. Ibid., 53/63.

100 La conciencia de sí en cuanto conciencia de lo otro, cf. Le Sens, 55/65. La noción de identidad narrativa: soy contado, identificado por lo otro, cf. Le Christ, 75 ss./80ss. 
estas disciplinas se sirve como mostración, como plausibilidad, pero siempre desde su propio logos, para expresar cómo se muestran dos aspectos confluyentes en la revelación. La salida-de-sí de Dios como donación y la salida-de-sí del ser humano que se convierte en acogida y aceptación. Ambas ek-sistencias convergen en la existencia concreta del hombre. En ella, la criatura tiene la capacidad y la posibilidad de ser atraído, y de actualizar la revelación y la salvación plenas, mostrando, así, la plena soberanía de Dios como anticipación del ésjaton definitivo. Dos ejemplos concretos se pueden encontrar en las argumentaciones que Gesché hace respecto de la identidad y de la esperanza.

\subsubsection{La hospitalidad, vínculo entre identidad y alteridad}

En la primera pone en relación los conceptos de alteridad-identidad y, a partir de ellos, con la imagen bíblica de la hospitalidad, expresa la fenomenología de la revelación. Comentando el relato de Emaús (cf. Lc 24,13-35), muestra cómo se da, qué elementos convergen y cuáles son sus efectos. El profesor de Lovaina lo sintetiza diciendo:

«[...] pero he aquí que por la doble gracia de su propia hospitalidad mediante la palabra y la hospitalidad de los otros que le acogen en su casa, él se vuelve huésped (segundo sentido de la palabra griega). Es el huésped que recibe y es recibido y que, desde ese momento, es reconocido en su identidad $»^{101}$.

Gesché habla de una «doble gracia», la de la palabra de Jesús revelando el cumplimiento de las Escrituras sobre su persona y la de la hospitalidad de los peregrinos al acogerlo en su casa. En el ejercicio de la hospitalidad confluyen «ambas gracias» y en su imbricación se despliegan nuevas dimensiones. Dios, que fundamenta la capacidad de apertura en el ser humano, se convierte, en su Hijo, en objeto de acogida. Por ello, el Hijo puede desvelar su identidad en los mismos gestos con los que se identificaba en su vida terrena - la fracción del pan-y, a partir de ahí, indicar la identidad del discípulo y su misión.

Esta dimensionalidad de la revelación puede ser designada en el vocabulario bíblico con la palabra xenos, que tiene la virtualidad de indicar al extranjero, a quien lo recibe hospitalariamente y al huésped. Con

101 Le Sens, 56/67. 
ella se muestra, igualmente, la conversión de la conciencia en todo acto de revelación. Así, en un mismo movimiento - la revelación-, se distinguen dos momentos en el sujeto pasivo: conmoción y conversión. El sujeto es iluminado en su conciencia por una presencia que se muestra de manera diferente a como antes lo hacía — «entonces se les abrieron los ojos»- Esta novedad provoca la conversión de su universo simbólico-referencial al aceptar el descubrimiento de las nuevas identidades, tanto la suya como la del revelador, y posibilita una nueva inteligencia capaz de releer y proyectar la historia de manera diferente — «¿no estaba ardiendo nuestro corazón...? [...] Y, levantándose al momento, se volvieron a Jerusalén»-. Como dice Gesché, «recibiendo ese don de Dios, el hombre va a encontrarse en el mismo corazón de la gracia de su humanidad ${ }^{102}$. Desde esta realidad de apertura y acogida, los lugares clásicos de la revelación - la Escritura, la tradición, la Iglesia, el hermano, etc.se muestran como lugares a los que abrirse y acoger, para descubrir, en ellos, la identidad del Dios que los ha inaugurado y la de quien los acoge. Sin duda una perspectiva sugerente en el actual contexto de marcado individualismo, a la vez que resulta un correctivo interno de esos mismos lugares — sobre todo los que están sujetos al devenir de la historia-, que están llamados a dar a conocer, a remitir, incluso sacramentalmente, al Dios que los fundamenta.

\subsubsection{El deseo, manifestación de la esperanza}

El segundo aspecto donde Gesché muestra con cierta claridad el acontecer de la salvación, gira en torno a sus desarrollos sobre la esperanza y el sufrimiento. En concreto en una de sus expresiones: el deseo.

El deseo es el impulso permanente, siempre insatisfecho, por el que se imaginan las cosas de otra manera. Ellas pueden - deben- ser distintas. La esperanza nos lanza a un destino cuyo eco resuena en el hombre en la figura del deseo, como si el ser humano tuviera inscrito el modelo conforme al cual debieran ser las $\operatorname{cosas}^{103}$. Este deseo pone de manifiesto el origen del hombre y también su destino, pero desde su historicidad, tomando en cuenta la realidad, aunque sea dolorosa y terrible; como vemos, A. Gesché asume en su discurso todos los condicionamientos de la

\footnotetext{
102 Ibid., 87.

103 Cf. Ibid., 93.
} 
existencia y es bien consciente de sus limitaciones, contra toda crítica materialista. Por eso podríamos decir que, al hablar del deseo, se realiza la revelación sub-contrario. En el deseo se muestra y se desvela la plenitud de la salvación por la distancia constatada entre su realización presente y la esperada en la plenitud de los tiempos. En ocasiones esta distancia es experimentada por la simple tensión hacia el futuro, en otras bajo el sufrimiento, la fatiga y la desdicha.

Las características de la esperanza — fiabilidad, seguridad — se fundamentan desde el logos cristiano en la fe. Por ello la esperanza está inscrita en su mismo lugar y participa de sus características y potencialidades ${ }^{104}$. Pero lo que en este momento desarrollamos en torno al deseo-esperanza es cómo se muestra ante el sufrimiento y la limitación, con la hipótesis de que, en su fenomenicidad, podemos establecer conexiones con el desvelamiento de la salvación, aunque éstas sean expresadas bajo la forma contraria a su naturaleza. Hipótesis que creemos no está desencaminada ni desdice el misterio divino; al fin y al cabo, la fe cristiana afirma el misterio de la cruz como expresión de la salvación, como manifestación de la Gloria de Dios, como evento trinitario de plenitud y densidad escatológicas.

La esperanza, expresada en el discurso del teólogo de Bruselas en el deseo subjetivo, es reclamo y grito desgarrador que llama a convertir los condicionamientos en condiciones ${ }^{105}$. Es una resistencia interior frente a todo impedimento y limitación, desbordando «el nivel de unos horizontes donde sólo hay soluciones inmediatas y prácticas» ${ }^{106}$. La reticencia por encerrarse en los condicionamientos de la historia y la distancia constatada entre la finitud y la infinitud, crean un ámbito de holgura que posibilita la imaginación, la invención y la creación de posibilidades siempre nuevas. Es cierto que hay impedimentos que, por desgracia, se ciernen como infranqueables, pero la fe invita a no crear más, a resistir e ir más allá de todo límite. Por este espacio libre de todo dominio que aporta la fe, por la diferencia radical entre la existencia y aquello a lo que ella misma remite — ek-sistencia—, se puede afirmar la potencialidad salvífica de tales acontecimientos. En ellos, el hombre puede percibir la voluntad salvífica de Dios en la oscuridad de sus días y en la ceguera de sus horizontes: «El sufrimiento tiene un significado, no por su propia gracia, sino por

\footnotetext{
104 Cf. Ibid., 131.

105 Cf. Ibid., 105.

106 Ibid., 108.
} 
su inclusión en un plan más amplio» ${ }^{107}$. En esta nocturnidad amenazante del sufrimiento, donde parece que Dios se muestra absconditus y su proyecto olvidado, el hombre puede manifestarse como revelatus y con ello desvelar que la diferencia radical entre el yugo de la esclavitud que vive y la libertad de su identidad a los ojos de Dios es expresión de la no-indiferencia de Dios respecto de él: «Puro acto de fe que hacemos al confiar, sin descanso, nuestro sufrimiento al cuidado de Dios» ${ }^{108}$. Por eso, la trascendencia del Dios cristiano tiene un componente ético, siempre es un Dios-de. No es una divinidad de corte cosmológico, sino personal. Sale al encuentro-de, adviene-a, visita-a, tiene como destino primero la persona y, en cada una, a la humanidad y al cosmos. Con toda su grandeza, su espesor, su profundidad, su capacidad de padecer, el ser humano es objeto de amor puro, pues ése es su verdadero deseo en el grito contra la desdicha. En él, no grita por la venganza, que en el fondo no la desea, ni lo redime, sino por la compasión que sólo puede hacer soportable y «saludables» tales situaciones. Una compasión excesiva, un amor exuberante —Dios mismo_- es lo reflejado — revelado— en su forma contraria.

\section{CONCLUSIÓN E INVITACIÓN}

De las geniales intuiciones de Adolphe Gesché, que hemos tratado de esbozar bajo el principio de salutarité, su mayor logro, a nuestro entender, reside en su carácter práctico. No entendido como moralización de lo que el cristiano debe hacer o pensar, peligro del que siempre se mostraba precavido, sino como concreción de lo que él entendía que debía ser la teología. Lejos de quedarse en un discurso formal, necesario pero vacío, daba contenido en sus escritos indicando cómo debía realizarse.

No pocas veces, en el ámbito teológico y eclesial —quizá como en otros-, ciertos slogans, frases que hacen fortuna y lugares comunes, jalonan discursos, artículos o libros, sin ir más allá de ellos mismos. Incapaces de padecer la «paciencia del concepto» (K. Rahner), acaban por agotarlos por su mero enunciado, cuando no por vaciarlos de contenido. El principio de capacidad salvífica, de salutarité, gracias a la pericia y dedicación del maestro de Lovaina, no ha sufrido esa suerte, sino que ha podido ser

\footnotetext{
107 A. Gesché. Le mal et la lumiere. o. c., 147-148.

108 Ibid., 148.
} 
fecundado con la entrega generosa de su creador, volviendo a dar vida a algunas de las mejores palabras de la tradición eclesial que han quedado en desuso; bien por silenciarlas, impidiendo su cuestionamiento, o bien por dejar de escucharlas, porque creíamos que ya lo habían dicho todo.

Una mirada crítica - todos la tenemos- sobre el desarrollo de Dieu pour penser, quizá eche en falta elementos de la dogmática, o se ruborice ante afirmaciones arriesgadas, o se pierda por la ausencia de un desarrollo sistemático — entendido de forma escolar-, pero lo que es innegable es que, en su limitación, Dieu pour penser da que pensar. No dejando las cosas cerradas, invita a ir más allá. Quizá sea ésta una de las expresiones de la necesaria salvación que, quizá, requiera la inteligencia de la fe en general y el ejercicio teológico en particular. Una salvación que quiere comunicar, dar conceptos, palabras, inteligencia, a la única salvación de la cual es testigo: la manifestada en Jesucristo.

Como decimos, quizá la teología debiera ir más allá de su propio círculo, de su propia autojustificación, entendida como acumulación de referencias internas, a la manera de dicta probantia, y escuchar -independientemente del orden-, el clamor de la humanidad, como el Dios de Moisés (cf. Éx 3,7), y las voces de la tradición cristiana, ambas como ecos de la Palabra. Quizá la teología debiera ir más allá, acomodando lo que dice y cómo lo dice a quien pueda escucharla, sin temor a perder su identidad, como canta el himno de la Carta a los filipenses sobre Cristo (cf. Flp 2,6-11). Quizá el principio de salutarité tiene en esa desinstalación su lugar propio, pues invita a acoger la gracia que sólo Dios puede dar bajo la condición peregrina de su discurso. Quizá, sea ésta su invitación. Quizá. Lo que es seguro es que la obra de Adolphe Gesché da testimonio de ello.

\section{REFERENCIAS}

Agustín de Hipona. Confesiones. Traducido por J. Cosgaya. Madrid: BACMinor, 2007.

Bourgine, Benoît, Paulo Rodrigues, Paul Scolas, dirs. La margelle du puits. Adolphe Gesché, une introduction. Paris: Cerf, 2013.

García Mourelo, Santiago. "La monstratio theologica de Adolphe Gesché. Inspiración teológico-fundamental de su obra". Estudios Eclesiásticos 92 (2017): 3-32. https://revistas.comillas.edu/index.php/ estudioseclesiasticos/article/view/7811 
García Mourelo, Santiago. "El 'principio de responsabilidad' en la teología de Adolphe Gesché”. Estudios Eclesiásticos 96, n. 376 (2021): 87-131. https://doi.org/10.14422/ee.v96.i376.y2021.003

Gesché, Adolphe. Fichier d'Adolphe Gesché, 1928-2003. Disponible bajo acreditación en https://bib.uclouvain.be/gesche/fr

Gesché, Adolphe. "Teología dogmática”. En Iniciación a la práctica de la teología, I. Introducción, editado por Bernard Lauret y Francois Refoulé, 270-292. Madrid: Cristiandad, 1984 (1982).

Gesché, Adolphe. Le mal. Dieu pour penser I. Paris: Cerf, 1993. (Trad. esp. El mal-El hombre. Salamanca: Sígueme, 1995).

Gesché, Adolphe. L'homme. Dieu pour penser II. Paris: Cerf, 1993. (Trad. esp. Esp. El hombre. Salamanca: Sígueme, 2002).

Gesché, Adolphe. Dieu. Dieu pour penser III. Paris: Cerf, 1994. (Trad. esp. Dios-El Cosmos. Salamanca: Sígueme, 1997).

Gesché, Adolphe. Le Cosmos. Dieu pour penser IV. Paris: Cerf, 1994. (Trad. esp. Dios-El Cosmos. Salamanca: Sígueme, 1997).

Gesché, Adolphe. La Destinée. Dieu pour penser V. Paris: Cerf, 1995. (Trad. esp. El destino. Salamanca: Sígueme, 2001).

Gesché, Adolphe. Le Christ. Dieu pour penser VI. Paris: Cerf, 2001. (Trad. esp. Jesucristo. Salamanca: Sígueme, 2002).

Gesché, Adolphe. Le Sens. Dieu pour penser VII. Paris: Cerf, 2003. (Trad. esp. El sentido. Salamanca: Sígueme, 2004).

Gesché, Adolphe. Pensées pour penser I. Le mal et la lumiere. Paris: Cerf, 2003.

Gesché, Adolphe. La Teología. Salamanca: Sígueme, 2017.

Küng, Hans. Ser cristiano. Madrid: Cristiandad, 1977. 
